\title{
Bireysel Emeklilik Fonları ve Cari Açık Arasındaki Illişki: Türkiye Örneği
}

\section{Relationship of Between Private Pension Funds and Current Account Deficit: A Case of Turkey}

Orkun ÇELIK', 0000-0002-8594-6852 Elif ERER ${ }^{2}$

\begin{abstract}
ÖZET
Bu çalışmanın amacı, 2004:Ç1-2016:Ç2 dönemi için Türkiye'de 2003 yilından beri uygulanmakta olan bireysel emeklilik sistemi ile elde edilen fonların, cari açık ile olan ilişkisini incelemektir. Söz konusu değişkenler arasındaki kısa ve uzun dönem arasındaki ilişki incelenirken, yapısal kırılmaları dikkate alan Gregory-Hansen eşbütünleşme analizinden, FMOLS ve CCR modellerinden ve TodaYamamoto nedensellik testinden yararlanılmıştır. Yapılan analiz sonucunda, uzun dönemde bireysel emeklilik fonları ile cari açık arasında negatif yönlü bir ilişki olduğu, bununla birlikte kısa dönemde ise anlamlı bir ilişki olmadığı görülmüştür. Ayrıca, hata düzeltme mekanizmasının işlediği ve kısa dönemde ortaya çıkan şokların bir yıl sonra ortadan kalktığı sonucuna ulaşılımıstır.
\end{abstract}

Anahtar Kelimeler: Cari Açık, Bireysel Emeklilik, Tasarruf, Yatırım

\section{GíRiş}

Türkiye'de cari açığın gayri safi yurtiçi hâsılaya oranı 2011-2015 dönemi için, OECD ülkeleri içerisinde en büyük paya sahip olan ülkeler arasında yerini almaktadır. (Abbasoğlu vd, 2017:1). Dünya ekonomisi ve dolayısıyla dünya ticaretindeki hızlı gelişmelerle birlikte, Türkiye'de cari açık, giderek artan bir şekilde ekonominin önde gelen sorunlarından biri olmuştur (Doğruel ve Doğruel, 2010: 50). Bu durum, özellikle son dönemde birçok iktisatçının daha fazla ilgisini çekmeye başlamıştır. (Abbasoğlu (2017), Beşel (2017), Yiğitbaş (2017), Turan (2016), Soydan (2016), Başarır ve Erçakar (2016), Yurdakul ve Cevher (2015), Yurdakul ve Uçar (2015), Dinçer ve Yaşar (2015), Özdamar

\begin{abstract}
The aim of this study is to examine the relation between the funds obtained by the private pension system, which has been implemented since 2003 in Turkey for the period of 2004:Q12016:Q2, and the current account deficit. While examining realtionship of between in the short run and long run, Gregory-Hansen Cointegration test with structural breaks, the FMOLS and CCR models and the Toda-Yamamoto causality test were used. Recording to results of the analysis, it was found that there was a negative relationship between the private pension funds and the current account deficit in the long run but there was no statistically significant relationship in the short term. In additon, error correction mechanism operates and the short run shocks disappear after a year.
\end{abstract}

Key Words: Current Account Deficit, Private Pension, Saving, Investment

(2015), Kara ve Sarıkaya (2014), Murat vd (2014), Insel ve Kayıkçı (2012) gibi). Yapılan çalışmalarda, cari açığın sürdürülebilirliği, belirleyicileri ve finansman yöntemleri incelenmesine rağmen, finansman araçlarından biri olarak düşünülen ve kalkınma planlarında da sıklıkla yer verilen bireysel emeklilik fonlarının, cari açık üzerindeki etkisine dair ampirik bir çalışmaya rastlanmamıştır.

Bu çalışmanın amacı da, 2003 yılından beri uygulamaya başlanılan bireysel emeklilik sisteminden elde edilen fonların, cari açık üzerindeki etkisini inceleyerek, literatürde ki bu açığı gidermek ve bu alana dair politika önerilerinde bulunmaktır. Bu kapsamda ikinci bölümde, ilk olarak cari açık ve tasarruf, ardın- 
dan tasarruf ve bireysel emeklilik fonları arasındaki teorik ilişki incelenmiştir. Üçüncü bölümde, bireysel emeklilik ve cari açığa ilişkin literatüre yer verilmiştir. Dördüncü bölümde, Türkiye'de ki tasarruf yetersizliği ile bireysel emeklilik sisteminin oluşumu ve cari açık ile olan ilişkisi güncel rakamlar yardımıyla incelenmeye çalışıımıştır. Beşinci ve altıncı bölümde, yapısal kırılmaları dikkate alan Gregory-Hansen eşbütünleşme testi, FMOLS ve CCR modellerinden ve Toda-Yamamoto nedensellik testinden yararlanarak, bireysel emeklilik fonları ve cari açık arasındaki ilişki analiz edilmiş olup elde edilen bulgulara yer verilmiştir. Sonuç bölümünde ise, bu bulgular ışığında Türkiye'deki tasarruf yetersizliği ve cari açığın finansmanına yönelik politika önerilerinde bulunulmuştur. Öte yandan, bilindiği kadarıyla, Türkiye için bireysel emeklilik fonları ve cari açık arasındaki ilişkiyi inceleyen ampirik bir çalışmaya rastlanılmamıştır. Bu çalışmanın literatüre beklenen katkısı ise, literatürdeki bu açığı gidermek ve özellikle uygulanan politikalar sonucunda elde edilen bireysel emeklilik fonlarının, cari açığı finanse etmede beklenen etkiyi yaratıp yaratmadığını göstermektir.

\section{TEORIK ÇERÇEVE}

Cari işlemler hesabı (CA), bir ülkenin, dünyanın geri kalanından ne ölçüde borç alabildiği ya da borç verebildiğini göstermektedir. Cari işlemler hesabı, üç farklı yolla tanımlanabilmektedir. İlki, kamu ve özel sektördeki, ulusal tasarruf ve yatırım arasındaki fark olarak ifade edilebilmektedir. İkincisi, dış ticaret dengesi (ihracat ve ithalat arasındaki fark) ve net gelir (faiz, kar payı gibi) toplamından oluşmaktadır. Son olarak, cari işlemler hesabı, sermaye ve finansal hesapların (sahip olunan ulusal varlıklardaki net değişim) aynadaki yansıması gibidir (Leszczuk ve Pojar, 2016: 3). Cari işlemler hesabının, ikinci tanımından yola çıkarak, tasarruf ve cari işlemler hesabı arasındaki teorik ilişkinin gösterilmesinde, temel ulusal hesaplamalar yönteminden yararlanılmaktadır. Bu amaçla, bir ülkenin gayri safi ulusal hasılası;

$$
G N P_{t}=Y_{t}+r_{t} B_{t}
$$

şeklinde yazılmaktadır. Denklemde, $Y_{t}$, ülkenin toplam yurtiçi hasılasını $r_{t} B_{t}$ ve ise ülkenin net yurtdışı gelirlerini göstermektedir. Yani, $t$ zamanda net yabancı varlık stokunun $\left(B_{t}\right), r_{t}$ uluslararası faizi üzerinden getirisini ifade etmektedir. Ayrıca, gayrisafi yurtiçi hâsıla $\left(Y_{t}\right)$ ise özel sektör tüketimi (C), kamu harcamaları (G), yatırım (I) ve net yurt dışı talebi (NX) (ihracatın, ithalattan fazla olması durumu) toplamın- dan oluşmaktadır. $N X_{t}$, ticaret dengesi olarak da tanımlanmaktadır.

$$
Y_{t}=C_{t}+G_{t}+I_{t}+N X_{t}
$$

Bu eşitlikten yola çıkarak, genellikle cari işlemler hesabı $\left(C A_{t}\right)$ dış ticaret dengesi ve net yurtdışı gelirleri toplamı olarak tanımlanmaktadır. Bu durumda cari işlemler denklemi;

$$
C A_{t}=N X_{t}+r_{t} B_{t}=G N P_{t}-\left(C_{t}+G_{t}+I_{t}\right)
$$

Gayrı safi ulusal hâsıla ile özel ve kamu kesimi harcamaları toplamı arasındaki fark, ulusal tasarrufu ifade etmektedir. Bu nedenle cari işlemler, ulusal tasarruf ve yatırımlar arasındaki farka eşittir (Olivei, 2000: 4-5; Krugman ve Obstfeld, 1997: 311; Uygur, 2012: 4 );

$$
C A_{t}=S_{t}-I_{t}
$$

Ulusal tasarruflar $\left(S_{t}\right)$ ise kamu ve özel sektör tasarrufları toplamından oluşmaktadır. $S_{t}=S_{t}^{p}+S_{t}^{g}=C A_{t}+I_{t}{ }^{\prime}$ dir. $S^{p}$ ve $S^{g}$ sirasiyla özel ve kamu tasarruflarını göstermektedir (Krugman ve Obstfeld, 1997: 312);

$$
\begin{aligned}
& S_{t}^{p}=Y_{t}-T_{t}-C_{t} \\
& S_{t}^{g}=T_{t}-G_{t}
\end{aligned}
$$

Burada $T_{t}$ ve $G_{t}$, toplam vergileri ve toplam kamu harcamalarını ifade etmektedir. Bu durumda,

$$
C A_{t}=S_{t}^{p}+S_{t}^{g}-I_{t}=S_{t}-I_{t}
$$

$C A_{t}>0$ olması durumu cari fazlayı, $C A_{t}<0$ ise cari açığı ifade etmektedir (Knight ve Scacciavillani, 1998: 8). $S_{t}-I_{t}$, tasarruf-yatırım farkını ifade etmekte olup doğrudan cari açıkla ilişkili olduğu görülmektedir. Grafik 1'de, $I-S_{1}$ aralığı cari açığın ilk seviyesini göstermektedir. Tasarrufların artması durumunda, tasarruf eğrisi $S_{1}$ 'den $S_{2}{ }^{\prime}$ ye doğru sağa kayacaktır. Bu durumda cari açık azalarak $I-S_{2}$ düzeyine kadar gerileyecektir. Tasarruf eğiliminin artması, aynı faiz oranında daha fazla tasarruf edilmesini sağlayarak, yurtdışı fon ihtiyacının azalmasını sağlayacaktır. Böylesi bir durumda yapılan yapısal reformlar, finansal eğitimler ve makro ihtiyati tedbirler aracılığıyla emeklilik reformunun gerçekleştirilmesi, aşırı borçlanmanın önlenmesi ve tasarruf bilincinin artırılması yurtiçi tasarrufların artmasını ve cari açığın düşmesini sağlayacaktır (TCMB, 2015). 
Grafik 1: Tasarruf-Yatırım ve Cari Açık İlişkisi

Faiz Oranı

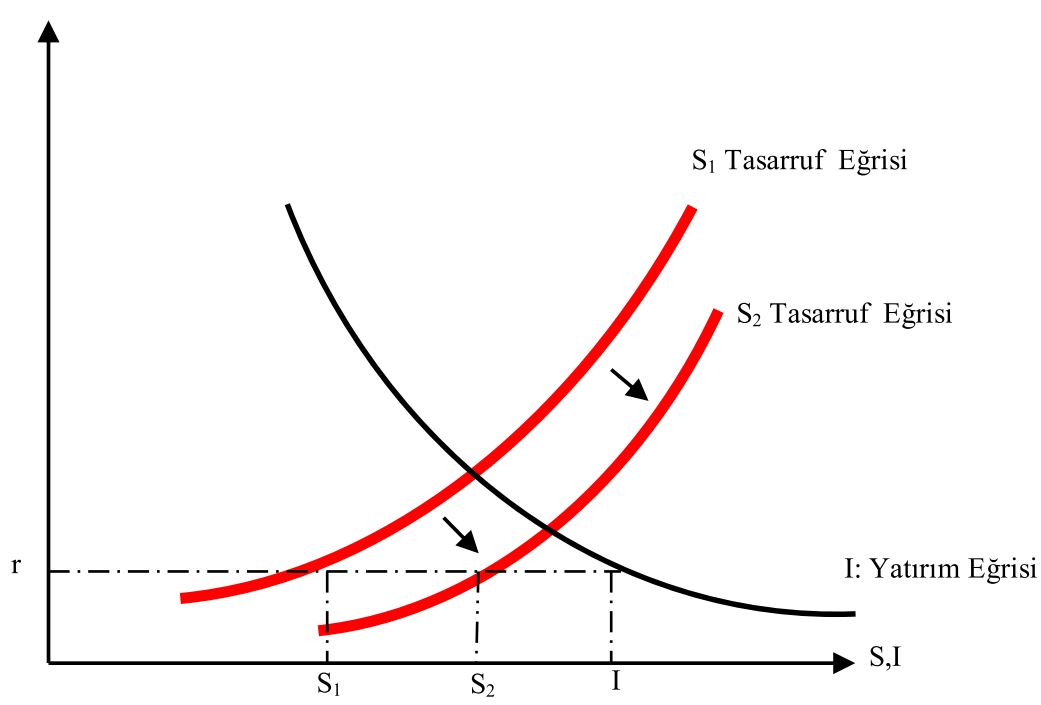

Kaynak: TCMB (2015)

Buradan yola çıkarak cari açıkta meydana gelecek olan bir azalmanın, yabancı tasarruflara olan aşııı bağımılığın azaltılması ile yüksek büyüme oranlarının sürdürülebilirliğinin ise ancak iç tasarrufların artırılması yoluyla mümkün olabileceği görülmektedir (Rijckeghem ve Üçer, 2008).

Iç tasarrufların arttırılmasında önemli bir rol alacağı düşünülen, bireysel emekliliğin tasarruflar üzerinde olumlu bir etki yaratıp yaratmadığı literatürde Cagan (1965), Katona (1965), Munnell (1976), Feldstein (1978), Munnell ve Yohn (1991),Gustman ve Steinmeier (1998), Attanasio ve De Leire (2002), Alessie vd (2013), Anton vd (2014), Lachowska ve Myck (2015) gibi birçok iktisatçı tarafından tartışımıştır. Bu çalışmalar içerisinde en çok atıf yapılan çalışmalardan biri olan Munnell (1976) çalışmasında,
Ando-Brumberg-Modigliani'nin yaşam döngüsü tasarruf modelinden yola çıkarak tasarruf ve bireysel emeklilik arasındaki ilişkiyi göstermeye çalışmıştır. Buna göre,

$$
C_{t}=\frac{1}{L E}\left[Y_{t}+(D-T) Y^{e}+A_{t-1}\right]
$$

Burada, D, öldüğü yaş, $T+L E^{\prime}$ ye eşittir.T ve $Y_{t}$ ise sırasıyla $t$ dönemdeki bireyin yaşını ve gerçek gelirini göstermektedir. $Y^{e}$, sonraki dönemde beklenen geliri, $A_{t-1}, t$ dönemi başında elinde bulunan varlıkları ve $L E$ ise ortalama yaşam süresini ifade etmektedir. Emeklilik sonrası gelecekte beklenen gelir, kazanılan gelir ve emeklilik ödeneği toplamından oluşmaktadır. Ayrıca modelde, gelecekte kazanılan gelirin $t$ dönemindeki gelire eşit olduğu varsayılmaktadır. Toplam beklenen gelir yeniden yazılacak olursa;

$$
(D-T) Y^{e}=(R-T) Y_{t}+(D-R) P E N
$$

$\mathrm{R}=$ beklenen emeklilik yaşı,

Bu nedenle,

$$
\begin{aligned}
& C_{t}=\frac{1}{L E}\left[Y_{t}(1+R-T)+(D-R) P E N+A_{t-1}\right] \\
& S_{t}=Y_{t}-C_{t} \\
& S_{t}=Y_{t}-\frac{1}{L E}\left[Y_{t}(1+R-T)+(D-R) P E N+A_{t-1}\right] \\
& =\frac{(D-R-1)}{L E} Y_{t}-\frac{(D-R)}{L E} P E N-\frac{A_{t-1}}{L E}
\end{aligned}
$$


şeklinde tasarruf denklemi yazılabilmektedir. $P E N$, beklenen emeklilik ödeneğini göstermektedir.

Bu alanda yapılan ampirik çalışmalardan Cagan (1965) ve Katona (1965) Amerika için, bireysel emekliliğin tasarruflar üzerinde pozitif bir etki yarattığını, Munnell (1976) ve Munnell ve Yohn (1991) ise, Cagan (1965) ve Katona (1965) aksine, bireysel emekliliği olan insanların diğerlerine göre daha az tasarruf yaptığı sonucuna ulaşmıştır. Feldstein (1978), Amerika'da bireysel emeklilik maaşlarındaki artışların, tasarruflar üzerinde olumsuz bir etki yaratmadığını ve az da olsa tasarrufların artmasına neden olabileceğini sonucunu elde etmiştir. Attanasio ve De Leire (2002) ise hane halkının bireysel emeklilik sözleşmelerini var olan tüketimlerini azaltarak finanse etmediğini, önceden var olan tasarruflarıyla finanse ettiği ve bireysel emeklilik sözleşmelerinin en fazla yüzde 9'nun ulusal tasarrufa katkı sağladığı sonucuna ulaşmışlardır. Alessie vd (2013) emeklilik varlıklarının, Avrupa ülkelerinde hanehalkı tasarrufları üzerindeki etkisini incelemiştir. Emeklilik varlıklarındaki her bir birim euro, emeklilik dışı varlıklarında 0,47 euroluk azalmaya neden olmaktadır. Anton vd (2014) tamamlayıcı bireysel emekliliğin, tasarruflar üzerindeki etkisini İspanya için incelemiştir. Buna göre, bu türeden emeklilik planlarının tüketimde bir azalmaya neden olmadığını ve bu nedenle ulusal tasarruflar üzerindeki pozitif etkisinin göz ardı edilebileceği sonucuna ulaşmışlardır. Lachowska ve Myck (2015) ise Polonya için kamu emeklilik varlıklarının tasarruflar ve harcamalar üzerindeki etkisini incelemişlerdir. Buna göre, emeklilik varlıklarındaki bir birimlik artış, hane halkı tasarrufları üzerinde 0,24 birimlik dışlama etkisi (crowding-out) yarattığı sonucuna ulaşmışlardır. Elde edilen bu sonuçlar, farklı yaş grupları için değişmektedir. Orta yaş grubunda dışlama etkisi $(0,54)$ daha yüksek iken, daha genç yaş gruplarında bu etki $(0,30)$ nispeten daha azdır.

\section{LITERATÜR}

Konuyla ilgili literatür incelendiğinde, özellikle cari açık ve tasarruf arasındaki ilişkinin dikkate alındığı ve tasarruf kalemlerinden biri olan bireysel emeklilik fonları ilgili kısıtlı bir literatür olduğu sonucuna varılmıştır. Elde edilen çalışmalar, şu şekilde özetlenmiştir.

Schimmelpfenning (2000), emeklilik reformu, özel tasarruflar ve cari açık arasındaki ilişkiyi genel denge analiziyle incelemiştir. Buna göre, geleceği öngören bireyler için borçla finanse edilen emeklilik reformları cari işlemler hesabını kötüleştirmekte, vergiyle finans- man durumunda ise cari işlemler hesabında bir değişikliğe neden olmamaktadır. Geleceği öngöremeyen bireyler için borçla finanse edilen emeklilik reformları, cari işlemler hesabında bir değişiklik meydana getirmemekte iken, vergiyle finansman durumunda ise cari işlemler hesabında bir iyileşme sağlamaktadır.

Murphy ve Musalem (2004), emeklilik fonları ve ulusal tasarruf arasındaki ilişkiyi incelemiştir. Çalışmada, 43 gelişmiş ve gelişmekte olan ülkenin 1960-2002 dönemi dikkate alınmış ve panel veri analizi yöntemini kullanmıştır. Elde edilen sonuçlara göre, emeklilik fonları zorunlu bir emeklilik programı sonucunda, ulusal tasarrufları arttırmaktadır. Ancak, gönüllü emeklilik sistemine dayalı bir kamu teşvik programı sonucunda oluşan emeklilik fonları, ulusal tasarrufları etkilemeyebilmektedir.

Bebczuk ve Musalem (2006), 48 gelişmiş ve gelişmekte olan ülke için, 1980-2004 dönemini panel veri analizi yöntemiyle incelenmiştir. Buna göre, emeklilik tasarrufunda 1 dolarlık bir artış, ulusal tasarrufları 0-20 cent arasında arttırmaktadır. Zorunlu katıım ve portföy bileşimi açısından sistem yapısı, sonuçları etkilememekte fakat, sistemin köklü bir yapıya sahip olması ulusal tasarruflar için önemli bir itici güç olmaktadır. Reformist ülkeler, diğer ülkelere oranla daha yüksek tasarruf oranları elde etmemektedir Ayrıca, tasarruflar ile yaşlı bağımlılı̆̆ı ve kentleşme oranı arasında negatif bir ilişki tespit edilmiştir. Tasarruf oranı ile büyüme oranı, enflasyon, ticaret hadleri ve cari işlemler dengesi arasında ise pozitif bir ilişki olduğu sonucuna ulaşılmıştır.

Yaraşır ve Yılmaz (2011), 20 OECD ülkesi için özel tasarrufların belirleyicilerini tespit etmeye çalışmıştır. 1999-2007 dönem aralığı dikkate alınıp, dinamik panel veri analizi yöntemi kullanılmıştır. Buna göre, bir önceki yıl tasarruf oranlarının, özel kredilerin, cari hesap dengesinin ve enflasyonun özel tasarruflar üzerindeki etkisi pozitif iken, kamu tasarrufları ve yaşlı bağımlılık oranının etkisi ise negatif bulunmuştur.

İşseveroğlu ve Hatunoğlu (2012), Türkiye için bireysel emeklilik fonlarının makroekonomik değişkenler üzerindeki etkisini SWOT analizi yöntemini kullanarak incelemiştir. Buna göre bireysel emeklilik sistemini güçlü yanları; şeffaf olması, vergi indirimi sağlaması, farklı portföy yatırımlarına sahip fonların kurulmasına olanak vermesi, faaliyet gösteren şirketlerin tamamına yakının yabancı sermayenin elinde bulunması nedeniyle, ülkemize ürün, operasyon, pazarlama ve organizasyon alanında 
know-how getirmesini sağlamasıdır. Zayıf yönleri, finansal kriz nedeniyle sisteme güvenin az olması, asgari getiri garantisinin olmamasıdır. Tehdit yönleri ise, vergi teşviklerinin amacına ulaşamaması, yabancı sermayenin yeterli düzeyde yurtiçine çekilememesidir. Fırsat yönleri, kişi başına düşen gelirin yükseleceği beklentisiyle fonlara olan ilginin artması ve kalkınmanın hızlanması, işsizliğin azalması böylece zaman içerisinde vergi gelirlerinin artması beklenmektedir.

Uyar (2012), Türkiye için bireysel emeklilik sistemi ile ekonomik göstergeler arasındaki ilişkiyi incelemiştir. 2004-2009 aylık veriler dikkate alınmış olup, VAR analizi kullanılmıştır. Buna göre, sertifika sayısı ile mevduat faizi arasında anlamlı bir ilişki tespit edilmiştir. Ayrıca, bir önceki dönemin mevduat faizi, ilgili dönemin sertifika sayısını etkilemekte olup, söz konusu dönemdeki sertifika sayısı ise bir sonraki dönemin mevduat faizini etkilediği belirlenmiştir.

Catalán ve Magud (2012), emeklilik reformları, cari açık ve çıktı arasındaki ilişkiyi incelemiştir. Çalışmada, dinamik genel denge modelinden yararlanılmıştır. Buna göre, emeklilik yaşını arttıran emeklilik reformla$\mathrm{rl}$, çıktı üzerinde büyük bir pozitif etkiye sahipken, cari işlemler üzerinde küçük (ve çoğu zaman olumsuz) bir etki yaratmaktadır. Ayrıca emeklilik maaşlarını düşüren reformlar, cari işlemler dengesini iyileştirmekte fakat, çıktı düzeyini azaltmaktadır. Karısıık emeklilik reformları (çalışma yaşını uzatan ve emeklilik maaşını düşüren) aynı anda çıktı düzeyini ve cari işlemler hesabını arttırabilmektedir.

Tülümce (2013), Türkiye için 1984-2010 döneminde üçüz açığın geçerliliğini incelemiştir. Çalışmada VAR yöntemi kullanılmıştır. Elde edilen sonuçlara göre, cari açıkla tasarruf yatırım açıkları arasında ilişkinin olduğu ve üçüz açık hipotezinin Türkiye için geçerli olmadığı sonucuna varılmıştır.

Özel ve Yalçın (2013a), 16 gelişmekte olan ülke için 1970-2010 döneminde özel emeklilik reformlarının yurtiçi tasarruf oranlarına olan etkisi incelenmiştir. Panel veri analizi yöntemi kullanılmıştır. Buna göre, gelişmekte olan ülkelerdeki bireysel emeklilikle ilgili reformların gecikmeli olarak yurtiçi tasarruf oranlarında yaklaşık 1,5 puana kadar artışa yol açabildiği tespit edilmiştir. Bu etki, ağırlıklı olarak zorunlu özel emeklilik sisteminin benimsendiği ülkelerde gözlenmiştir. Türkiye'de uygulanmakta olan gönüllü emeklilik sisteminin, yurt içi tasarruflar üzerindeki etkisi daha sınırlı olabileceği düşünülmektedir.

Brückner ve Pappa (2013), Sahra altı Afrika ülkeleri için yurtiçi tasarruflar ile cari açık arasındaki ilişki incelenmiştir. İki aşamalı en küçük kareler yöntemi kullanılmıştır. Buna göre, yurtiçi tasarrufların cari açık üzerindeki etkisi küçük ve istatistiksel olarak anlamsız iken, ticaret dengesi üzerinde pozitif ve anlamlı bir etki tespit edilmiştir. Yurtiçi tasarruflarla cari açık arasında bir ilişkinin olmamasının nedeni, net cari transferlerin güçlü bir konjonktür karşıtı olarak tepki vermesidir.

Selim ve Çelik (2014), 32 OECD ülkesi için bireysel emeklilik fonlarının belirleyicilerini incelemiştir. 20052011 dönem aralığı dikkate alınmış ve panel veri analizi yöntemi kullanılmıştır. Buna göre, hane halkı tüketim harcamaları, kişi başına gayri safi yurtiçi hâsıla, erkeklerin ortalama emeklilik yaşı bireysel emeklilik fonlarını negatif ve anlamlı bir şekilde etkilemiştir. Buna karşın nüfus, sağlık harcamaları ve istihdam oranı bireysel emeklilik fonlarını pozitif etkilemiştir. Enflasyon ve kısa dönem faiz oranının emeklilik fonları üzerinde etkisinin olmadığı tespit edilmiştir.

Eren ve Ileri (2015), Türkiye'de 2013'ten beri uygulanmaya başlanan yeni emeklilik sisteminin tasarruf oranı, sermaye stoku ve bireylerin uzun dönem refahı üzerindeki etkisini incelemiştir. Çok dönemli OLG modelinden yararlanılmıştır. Elde edilen sonuçlara göre, bu yeni sistemle net tasarruf oranı $\% 0,27$ oranında artmaktadır. Bireysel emeklilik varlıklarındaki \% 23,9'luk bir artış, artan tasarruflara katkı sağlamaktadır. Fiziki sermaye stokunda \% 15,6'lık bir artış sağlamaktadır. Uzun dönem refah analizine göre, yeni doğmuş bir birey, bireysel emeklilik sisteminin uygulandığı ekonomide doğmayı tercih etmektedir. Bireysel emeklilik hesapları üzerinden alınan ücretlerin azaltılması, net tasarruf oranı ve fiziki sermaye stokunda kayda değerli bir gelişmeyi sağlamaktadır.

Sezgin vd (2015), Türkiye için cari açık sorunu ve bu bağlamda, tasarrufların önemi ve bireysel emeklilik sistemini incelenmiştir. Türkiye'de ki cari açık sorununun temel nedeni tasarruf-yatırım dengesizliğinin olduğu, bununda yatırımların fazlalığından olmayıp tasarrufların aşırı yetersizliğinden kaynakladığını ifade etmektedirler. Ayrıca çalışmada, tasarruf hacminin arttırılmasına yönelik uygulanılan bireysel emeklilik sisteminin bu sorunun çözümünde bir belirleyici olabileceği çıkarımı da yapılmaktadır.

Başar vd (2016), 14 OECD ülkesi için, bireysel emeklilik, tasarruf oranı ve cari açık arasındaki ilişkiyi incelemiştir. 2005-2014 dönem aralığı dikkate alınmış olup, panel nedensellik yöntemi kullanılmıştır. Elde dilen sonuçlara göre, iki gecikme için tasarruf ve 
bireysel emeklilik fonlar arasında çift yönlü; bireysel emeklilik fonları ile cari açık arasında çift yönlü; cari açıktan tasarrufa doğru tek yönlü bir nedensellik ilişkisi elde edilmiştir.

Kaygısız vd (2016), Türkiye için tasarruf, yatırım, cari açık ve büyüme arasındaki ilişkiyi incelemiştir. 1980-2014 verileri kullanılarak, Toda-Yamamoto ve Granger nedensellik analizinden yararlanılmıştır. Buna göre, büyüme, tasarruf ve yatırımlar arasında herhangi bir nedensellik ilişkisi tespit edilmemiştir. Bununla birlikte büyüme, tasarruf ve yatırımlardan cari dengeye doğru tek yönlü nedensellik ilişkisi bulunmaktadır. Elde edilen bulgular, Türkiye'de cari açığın yüksek büyüme dönemlerinde hızla arttığı savını doğrulamaktadır.

Çiğdem (2017), MENA ülkeleri için tasarruf ve cari açık arasındaki ilişkiyi incelemiştir. 1971-2015 dönemi incelenmiş olup, eşbütünleşme ve sınır testinden yararlanılmıştır. Elde edilen sonuçlara göre, Mısır, Kuveyt, Libya, Suriye ve Tunus'un aksine, Bahreyn, Ürdün, Fas, Sudi Arabistan ve Sudan'da uzun dönemde tasarruf ve cari açık arasında bir ilişki olduğu sonucuna ulaşılmıştır.

\section{TÜRKIYE'DE TASARRUF, BIREYSEL EMEKLILIK VE CARI AÇIK İLişKisi}

Türkiye'de cari açı̆̆ın temel nedeni, tasarruf yetersizliği olması nedeniyle, bu alanda yapılacak olan ilk adımda da tasarrufların arttırılması olacaktır
(Çoban ve Çoban, 2016: 2001). Fakat Türkiye, özellikle finansal sistemde serbestleşmeye geçtikten sonra tasarruf oranı düşen ülkeler arasında yer almıştır. Tasarruf oranında meydana gelen bu düşüş, Türkiye ekonomisini yabancı tasarruflara, diğer bir ifadeyle sermaye hareketlerine muhtaç bir hale getirmiştir (Çolak ve Öztürkler, 2012: 16). Grafik 2'de görüldüğü gibi, cari işlemler dengesiyle benzer seyir izleyen tasarruf-yatırım açığı, 2001 krizinden sonra önemli oranda artmış, sonraki 10 yıl boyunca yüksek düzeydeki seyrini sürdürmüştür (Dünya Bankası, 2013: 11). Türkiye'deki yurtiçi tasarruf oranındaki bu düşüşün asıl nedeni, özel kesimden kaynaklanmaktadır. Hanehalkı tasarruflarındaki gözle görünür düşüş ve özel yatırımlardaki artış, özel kesim tasarruf-yatırım farkının 2001 yılından itibaren hızla düşmesine ve 2005 yılından itibaren ise negatife dönmesine neden olmuştur (Özel ve Yalçın, 2013b: 2).

Bu nedenle, son dönemde gündeme gelen bireysel emeklilik sistemi gibi yöntemler uygulanarak iç tasarrufları artırma çabası, cari açığı düşürme eyleminin bir parçası olmuştur (Eğilmez, 2013). Nitekim bireysel emeklilik sistemi tasarlanırken sadece sosyal güvenlik fonksiyonu dikkate alınmayıp, aynı zamanda ülkenin intiyaç duyduğu uzun vadeli yatırımlar için gerekli fon arzının ve kamunun uzun vadeli borçlanma olanakIarının sağlanmasıyla birlikte toplam yurtiçi tasarrufların arttırıması gibi amaçlar da dikkate alınmaktadır (Yılmaz ve Yaraşır, 2009:113).

Grafik 2: Türkiye'de Tasarruf-Yatırım Dengesi ve Cari İşlemler Dengesi (\% GSYiH) )(1983-2014)

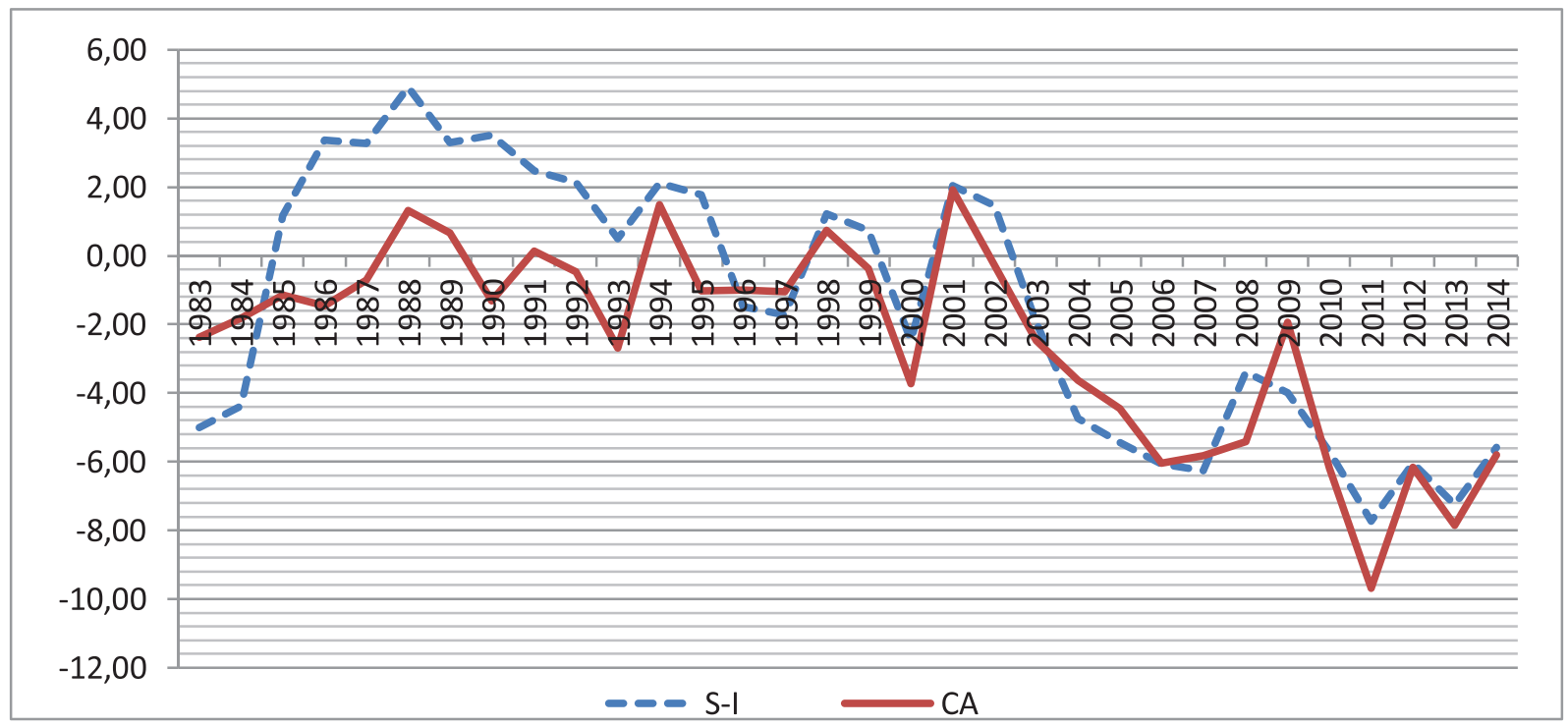

Kaynak: Kalkınma Bakanlığı́ndan alınan veriler tarafımızca düzenlenmiştir.

Not: CA: Cari İşlemler Dengesi (\%GSYiH)

S-I: Tasarruf Yatırım Dengesi 
Bu kapsamda, Türkiye'de bireysel emeklilik sistemi, 7 Ekim 2001 tarih ve 4632 sayılı "Bireysel Emeklilik Tasarruf ve Yatırım Sistemi Kanunu" ile yürürlüğe girmiş olup, 27 Ekim 2003 tarihinde işleme başlamıştır (İşseveroğlu ve Hatunoğlu, 2012: 156). Bu kanunun amacı (4632 sayılı Bireysel Emeklilik Tasarruf ve Yatırım Sistemi Kanunu);

"Kamu sosyal güvenlik sisteminin tamamlayıcısı olarak, bireylerin emekliliğe yönelik tasarruflarının yatırıma yönlendirilmesi ile emeklilik döneminde ek bir gelir sağlanarak refah düzeylerinin yükseltilmesi, ekonomiye uzun vadeli kaynak yaratarak istihdamın artırılması ve ekonomik kalkınmaya katkıda bulunulmasını teminen, gönüllü katılıma dayalı ve belirlenmiş katkı esasına göre oluşturulan bireysel emeklilik sisteminin düzenlenmesi ve denetlenmesidir".

Bu amaçla ilk olarak 27 Ekim 2003 tarihinde uygulanmaya başlanan bireysel emeklilik sisteminin, günümüzde dünya ekonomileri içerisindeki payı oldukça düşük kalmıştır. Grafik 3'te de görüldüğü gibi, 34 OECD ülkesi içerisinde Türkiye'deki bireysel emeklilik fonlarının GSYiH içerisindeki payı \% 5,5 iken, OECD ülkelerinin basit ortalaması ise $\% 49,5$ civarındadır.

Türkiye'deki bireysel emeklilik fonlarının diğer ülkelere kıyasla bu denli düşük olmasının nedenleri arasında, emeklik sisteminin yeni uygulanan bir sistem olması ve diğer ülkelerin emeklilik fonları için yapmış oldukları teşvik reformları gösterilebilmektedir. Grafik 4'te, bireysel emeklilik fonlarının 2004Ç1$2016 C ̧ 2$ dönemleri arasında GSYiH içerindeki payı ve cari açıkla olan seyri gösterilmektedir. Buna göre cari açığın özellikle küresel krizden sonra daha da derinleştiğini ve bireysel emeklilik fonlarıyla benzer bir seyir izlemediği söylenilebilmektedir.

Grafik 3: OECD Ülkelerinde Emeklilik Fonlarının GSYIH İ̧̧erisindeki Payları (\%) (2016)

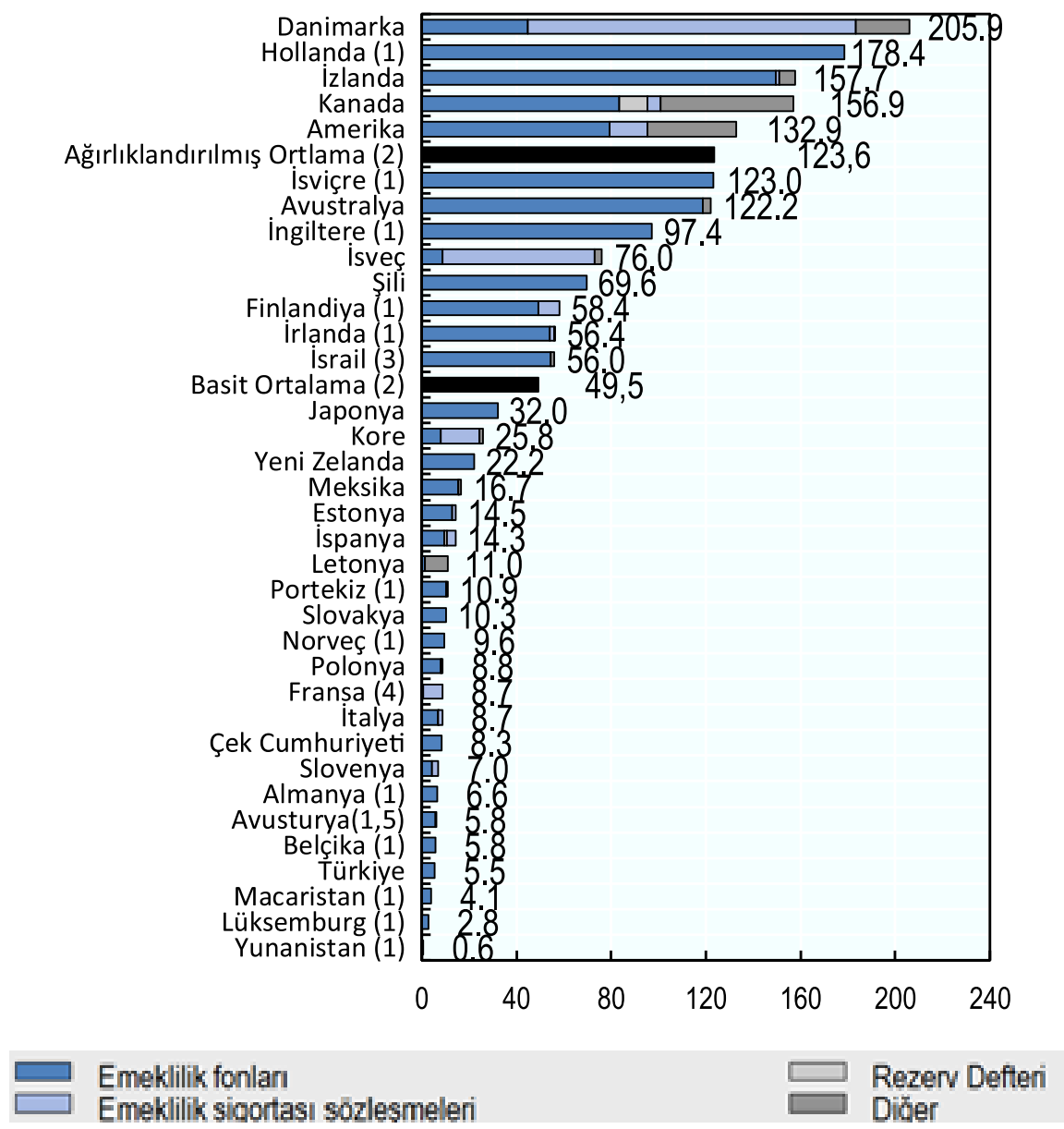

Not: (1) Tüm bireysel emeklilik sistemini kapsamamaktadır; (2) Ağırlıklı (toplam yatırımlarla) ve basit ortalama (bireysel emeklilik yatırımlarının GSYiHıya oranı); (3) Eski, yeni ve genel emeklilik fonları; (4) 2014; (5) 2013; (6) 2012 ; (7) 2011.

Kaynak: OECD (2016), Pension Market in Focus'den alınan veriler tarafımızca düzenlenmiştir. 
Grafik 4: Türkiye'deki Bireysel Emeklilik Fonları ve Cari Açığın GSYiH İçindeki Payı (\%)

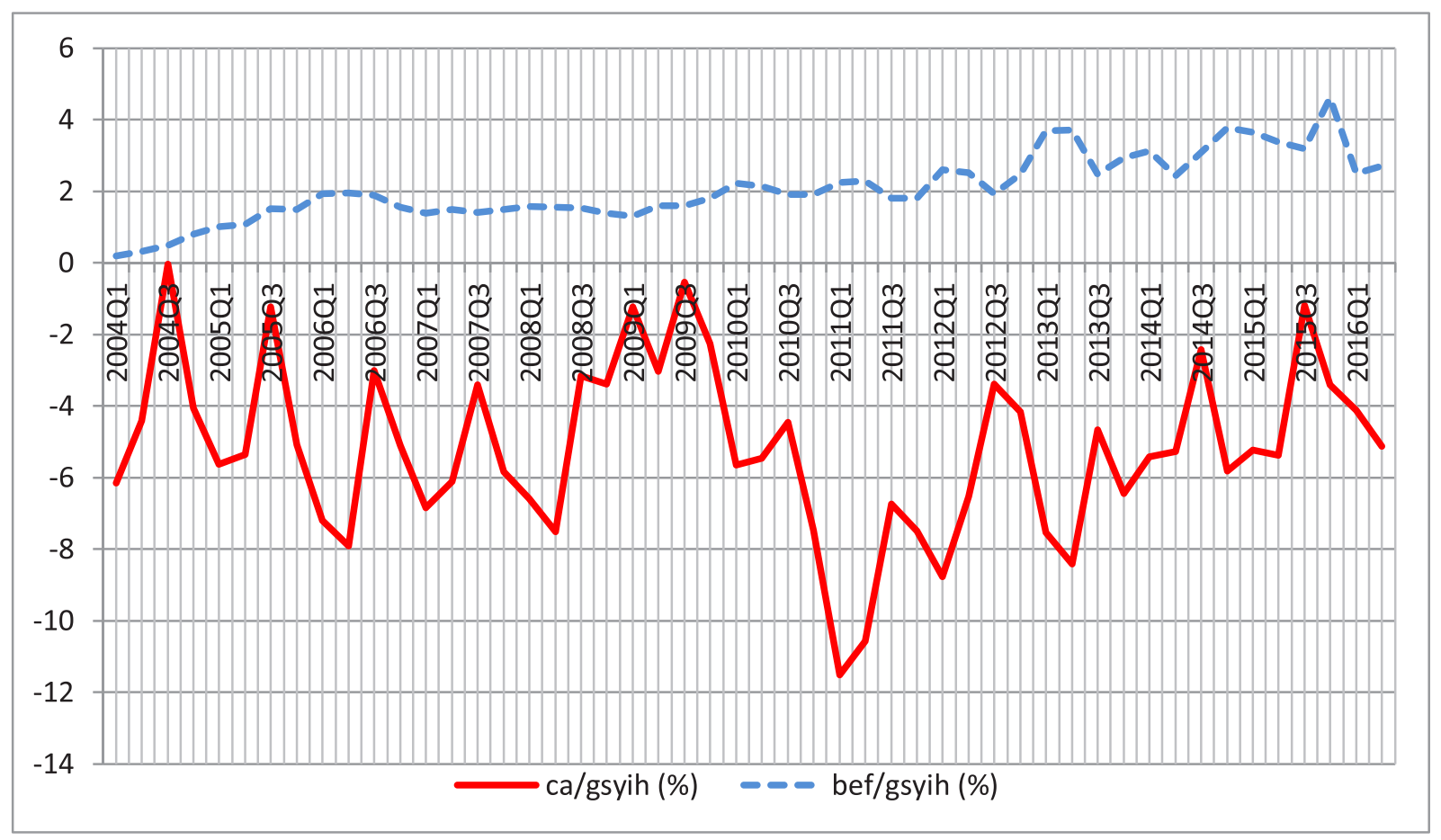

Kaynak: EGM ve TCMB EVDS'den alınan veriler tarafımızca düzenlenmiştir.

Çalışmanın literatüre iki açıdan katkı sağlaması beklenmektedir. Illk olarak, Türkiye'de cari açık sorununu giderici alternatif arayışlar kapsamında değerlendirilen bireysel emeklilik fonlarının cari açık üzerinde yaratmış olduğu etki analiz edilmeye çalışımıştır. İkinci olarak ise, cari açık ve bireysel emeklilik fonları arasındaki kısa ve uzun dönem ilişki Türkiye'de meydana gelen yapısal kırılmalar açısından ele alınmıştır. Çalışmada ilk olarak, ilgili literatür incelenmiş, daha sonra kullanılan yöntem ve elde edilen bulgulara yer verilmiştir. Son olarak sonuç ve öneriler kısmında çalışmadan elde edilen bulgularla Türkiye'de cari açık sorununa yönelik tavsiyelerde bulunulmuştur.

\section{AMPIRIK UYGULAMA}

\subsection{Model ve Veri Seti}

Çalışmada, literatürde sıkça kullanılan ve Krugman ve Obstfeld (1997), Knight ve Scacciavillani, (1998), Olivei (2000) tarafından da gösterilen temel cari işlemler dengesi modelinden yararlanılacaktır. Buna göre,

$$
C A_{t}=S_{t}^{p}+S_{t}^{g}-I_{t}=S_{t}-I_{t}
$$

Türkiye'de bireysel emeklilik fonları, ulusal tasarrufun çok az bir kesimini temsil etmesine rağmen, çalışmada bireysel emeklilik fonlarının cari açıkla olan kısa ve uzun dönemdeki ilişkisi analiz edilecektir.

$$
C A_{t}=\alpha+\beta B E_{t}+e_{t}
$$

Denklemde $B E_{t}$ ve $C A_{t}$ sırasıyla, t zamandaki bireysel emeklilik fonları/gayri safi yurtiçi hâsılayı ve cari açık/gayri safi yurtiçi hasılayı ifade etmektedir. $\alpha$, sabit terimi ve $e_{t}$, hata terimini göstermektedir.

Model yorumlanırken, CA serisinin nasıl elde edildiği de önemlidir. CA verisi, negatif olarak elde edildiğinde, $\beta>0$ olması durumunda; $B E$ artışları $C A^{\prime} y ı$ azaltmaktadır. $\beta<0$ olduğunda; $B E$ artışları, CA'yı arttırmaktadır. CA, pozitif olarak alındığında ise $\beta>0$ olduğunda; $\mathrm{BE}$ artışları CA'yı arttırmakta, $\beta<0$ olduğunda da BE artışları, CA'yı azaltmaktadır (Göçer ve Peker, 2014: 99). Burada bireysel emeklilik fonları arttığında, cari açığında artması beklenmektedir. Dolayısıyla $\beta<0$ olması beklenmektedir.

Ayrıca çalışmada kullanılacak olan bireysel emeklilik fonları verisi, 2003 yılından itibaren haftalık olarak erişilebilmesine rağmen, cari açık verilerine aylık olarak 2005 yılından çeyreklik olarak 1991 yılından, yıllık olarak 1984 yılından itibaren sağlık bir biçimde ulaşılabilmektedir. Gayri safi yurt içi hâsıla verilerine ise çeyreklik düzeyde 1998 yılından itibaren erişilebilmektedir. Bu nedenle çalışmanın dönem aralığı, çey- 
reklik olarak belirlenmiştir. Bu durum ise, çalışmanın zaman boyutunu oldukça kısıtlamaktadır.

Bu çalışmanın amacı 2004:Ç1-2016:Ç2 dönemi için bireysel emeklilik fonları ile cari açık arasındaki kısa ve uzun dönemli ilişkiyi ortaya koymaktır. Çalışmada söz konusu ilişkiyi incelemek amacıyla çeyreklik bireysel emeklilik fonları ve cari açık değişkenlerinden yararlanılmıştır. Çeyreklik frekansta gözlemlenen zaman serileri genellikle periyodik hareketler göstermektedir. Bu nedenle, serilerden periyodik mevsimsel hareketleri arındırmak amacıyla TRAMO/ SEATSyöntemi kullanılmıştır. Bu yöntem ARIMA model tabanlı bir metottur. TRAMO başlangıçta periyodik ve mevsimsel fark düzeylerini belirlemek amacıyla serileri $A R(1)$ ve $A R M A(1,1)$ ile modellemektedir. En uygun ARMA modeli BIC kriterine göre belirlenmektedir. TRAMO dışa düşenleri kendiliğinden tanımlamakta ve işlem günleri gibi diğer regresyon değişkenlerini hesaplamaktadır. SEATS ise trend ve mevsimsel olarak düzeltilmiş bileşen olmak üzere iki bileşenin parametrelerini tahmin etmektedir. (Atuk ve Ural, 2002). Çalışmada kullanılan değişkenlere ilişkin açıklamalar ve veri tabanı Tablo 1'de yer almaktadır. Burada CA verisi, ödemeler dengesi analitik sunum aylık cari işlemler hesabı düzey değerleri, ortalama ABD Dolar kuru kullanılarak TL'ye çevrilmiştir. Ardından cari GSYiH serisine oranlanmıştır. BE verilerine ise, haftalık bireysel emeklilik fon verileri toplanarak çeyreklik veriye dönüştürülmüş ve cari GSYiH serisine oranlanmıştır.

Tablo 2'de bireysel emeklilik fonları ve cari açık değişkenlerine ilişkin özet istatistikleri yer almaktadır:

Tablo 2 incelendiğinde, bireysel emeklilik fonlarının GSYiH içindeki payının ortalama $\% 2,06$, cari açığın GSYiH içindeki payının ise -\%5,10 olduğu görülmektedir. 2004-2016 dönemi içinde cari açık değişkeninin GSYIH içindeki payının en yüksek $\% 0.23$, buna karşın bireysel emeklilik fonları değişkeninin GSYiH içindeki payının en yüksek \%4.67'dir. Standart sapma değerleri incelendiğinde, cari açık değişkeninin bireysel emeklilik fonlarına göre oynaklığının daha yüksek olduğu görülmektedir.
Tablo 2: Tanımlayıcı İstatistikler

\begin{tabular}{lll}
\hline & BE & CA \\
\hline Ortalama & 0.020698 & -0.051078 \\
Medyan & 0.020074 & -0.049618 \\
Maksimum & 0.046740 & 0.002378 \\
Minimum & 0.002549 & -0.099170 \\
Standart Sapma & 0.008846 & 0.019071 \\
Çarpıklık & 0.360757 & -0.225248 \\
Basıklık & 3.213846 & 3.759030 \\
Jarque-Bera & 1.179816 & 1.623068 \\
Olasılık & 0.554378 & 0.444176 \\
Gözlem Sayısı & 50 & 50 \\
\hline
\end{tabular}

\subsection{Metodoloji}

Çalışmada bireysel emeklilik fonları ve cari açık arasındaki ilişkiyi araştırmak için ilk olarak tek yapısal kırılamaya izin veren Zivot Andrews birim kök analizinden yararlanılmıştır. Zivot ve Andrews (1992), Perron testinde kırılma tarihlerinin dışsal olarak belirlenmesini eleştirmişlerdir. Zivot-Andrews testinde, alternatif hipotez altında kırılmanın meydana geldiği zamanın kesin olarak bilinmediği varsayılmaktadır. Zivot ve Andrews (1992), Perron (1989)'un kırılma noktalarını belirlemek için kullandığı prosedürü genişleterek Perron'un testini şartsız (unconditional) birim kök testine dönüştürmüşlerdir. Zivot-Andrews testinde kırılma tarihleri önceden bilinmemekte ve bu tarihler içsel olarak belirlenmektedir. Kırılma noktası $\lambda, \alpha^{i}=1(i=A, B, C)$, için tek taraflı t istatistiğini minimize ederek seçilmektedir. Çünkü istatistiğin çok küçük değerleri sıfır hipotezinin reddedilmesine neden olmaktadır. $\hat{\lambda}_{\text {inf }}^{i}$ i modeli için minimize edilen değeri gösterirken;

$$
t_{\widehat{\alpha}^{i}}\left[\widehat{\lambda}_{\text {inf }}^{i}\right]=\inf _{\lambda \in \Lambda} t_{\widehat{\alpha}^{i}}(\lambda), \quad i=A, B, C
$$

Perron'un ADF test stratejisi izlenerek, birim kökü test etmek için kullanılan regresyon denklemleri aşağıdaki gibidir:

Tablo 1: Bireysel Emeklilik Fonları ve Cari Açığa İlişkin Açıklama ve Veri Tabanı

\begin{tabular}{llll}
\hline $\begin{array}{l}\text { Değişkenler } \\
(2004: C ̧ 1-2016: C ̧ 2)\end{array}$ & Kısaltma & Açıklama & Kaynak \\
\hline Bireysel Emeklilik Fonları/GSYiH & BE & $\begin{array}{l}\text { Bireysel emeklilik fonlarının } \\
\text { mevsimsellikten arındırılmıştır. }\end{array}$ & Emeklilik Gözetim Sistemi \\
\hline Cari Açık/GSYiH & CA & Cari açık mevsimsellikten arındırılmıştır. & TCMB \\
\hline & & & \\
\hline
\end{tabular}




$$
\begin{aligned}
& y_{t}=\hat{\mu}^{A}+\hat{\theta}^{A} D U_{t}(\hat{\lambda})+\hat{\beta}^{A} t+\hat{\alpha}^{A} y_{t-1}+\sum_{j=1}^{k} \hat{c}_{j}^{A} \Delta y_{t-j}+\hat{e}_{t} \\
& y_{t}=\hat{\mu}^{B}+\hat{\beta}^{B} t+\hat{\gamma}^{B} D T_{t}^{*}(\hat{\lambda})+\hat{\alpha}^{B} y_{t-1}+\sum_{j=1}^{k} \hat{c}_{j}^{B} \Delta y_{t-j}+\hat{e}_{t} \\
& y_{t}=\hat{\mu}^{C}+\hat{\theta}^{C} D U_{t}(\hat{\lambda})+\hat{\beta}^{C} t+\hat{\gamma}^{C} D T_{t}^{*}(\hat{\lambda})+\hat{\alpha}^{C} y_{t-1}+\sum_{j=1}^{k} \hat{c}_{j}^{C} \Delta y_{t-j}+\hat{e}_{t}
\end{aligned}
$$

Burada $\lambda$ kırılma zamanını göstermektedir. $D U_{t}(\hat{\lambda})$ sabitte kırılmayı, $D T_{t}^{*}(\hat{\lambda})$ ise eğimde kırımayı ifade etmektedir. Eğert $>T \lambda$ ise $D U_{t}(\lambda)=1$, aksi durumda 0; eğer $t>T \lambda$ ise $D T_{t}^{*}(\lambda)=t-T \lambda$ , aksi durumda 0'dır. Zivot-Andrews testinde kırılma noktaları, $\widehat{\lambda}_{\text {inf }}^{i}$ ve $t_{\widehat{\alpha}^{i}}$ değerlerini minimize ederek $\widehat{T}_{B}=T \hat{\lambda}$ ile belirlenir (Zivot ve Andrews, 1992: 253254).

Çalışmada değişkenlerin birim kök analizi yapıldıktan sonra, her iki değişken arasında eşbütünleşme ilişkisinin olup olmadığı araştırılmıştır. Bu amaçla tek yapısal kırılmaya izin veren GregoryHansen eşbütünleşme analizinden yararlanılmıştır. Gregory ve Hansen (1996) örnek dönemi bilinmeyen bir tarihte yapısal değişime izin veren eş bütünleşik vektör önermişlerdir. Burada sıfır hipotezi eş bütünleşmenin olmadığını söyleyen diğer testler ile benzerdir, ancak alternatif hipotez diğer geleneksel testlerden daha farklıdır. Eş bütünleşme vektörü bir bilinmeyen nokta olduğunda değişmektedir. Bu durumda, standart eş bütünleşme testleri uygun olmamaktadır, çünkü bu testler alternatif hipotez altında eş bütünleşme vektörünün zamanla değişmediğini varsaymaktadır. Gregory ve Hansen (1996) eş bütünleşme testinde $A D F, Z_{\alpha}$ ve $Z_{t}$ testleri önerilmektedir. Gözlemlenen veri $y_{t}=\left(y_{1 t}, y_{2 t}\right)$, burada $y_{1 t}$ gerçek değerlidir ve $y_{2 t}$ bir m-vektördür. Yapısal değişimin olmadığı standart eş bütünleşme modeli aşağıdaki gibidir.

Model 1: Standart Eş bütünleşme

$$
y_{1 t}=\mu+\alpha^{T} y_{2 t}+e_{t}, \quad t=1, \ldots, n
$$

Burada $y_{2 t} \mathrm{l}(1)$ ve $e_{t} \mathrm{l}(0)^{\prime}$ dir. Bu modelde $\mu$ ve $\alpha$ m-boyutlu hiperdüzlemdir. Engle ve Granger (1987) eş bütünleşmeyi uzun dönem denge için kullanışlı bir model olarak tanımlamıştır. Model $1 \mu$ ve $\alpha$ 'nın zaman boyunca değişmediğini varsaymaktadır. Ancak, birçok uygulamada eşbütünleşme ilişkisinin belirli bir dönemde sağlandığı, daha sonra da yeni bir uzun dönem ilişkisine doğru kaydığı görülmektedir. Yapısal değişimi modellemek amacıyla, kukla değişkeni aşağıdaki gibi tanımlansın:

$$
\varphi_{1 \tau}= \begin{cases}0 & t \leq[n \tau] \\ 1 & t>[n \tau]\end{cases}
$$

Burada $\tau, 0$ ile 1 arasında değer almakta ve kırılma zamanlamasını ifade eden katsayıdır. Yapısal değişim sabitte, trendde ve rejimde kırılma olmak üzere üç şekilde ele alınmaktadır:

Model 2: Sabitte kırılma (C)

$y_{1 t}=\mu_{1}+\mu_{2} \varphi_{t \tau}+\alpha^{T} y_{2 t}+e_{t}, \quad t 1, \ldots, n$.

Burada $\mu_{1}$ kırılma önceki sabit terimi ve $\mu_{2}$ kırılma sırasında sabit terimdeki değişimi göstermektedir.

Model 3: Trend ve Sabitte Kırılma (C/T)

$y_{1 t}=\mu_{1}+\mu_{2} \varphi_{t \tau}+\beta t+\alpha^{T} y_{2 t}+e_{t}, t=1, \ldots, n$.

Model 4: Rejimde Kırılma (C/S)

$y_{1 t}=\mu_{1}+\mu_{2} \varphi_{t \tau}+\alpha_{1}^{T} y_{2 t}+\alpha_{2}^{T} y_{2 t} \varphi_{t \tau}+e_{t}, t=1, \ldots, n$

Burada $\mu_{1}$ ve $\mu_{2}$ sabitte karılma modelinde ifade edildiği gibidir. $\alpha_{2}$ kırılmadan önceki eğim katsayısını ve eğim katsayısındaki değişimi göstermektedir.

Test istatistikleri aşağıdaki gibidir (Greogy ve Hansen, 1996):

$$
\begin{aligned}
& Z_{\alpha}^{*}=i n f_{\tau \in T} Z_{\alpha}(\tau), \\
& Z_{t}^{*}=i n f_{\tau \in T} Z_{t}(\tau), \\
& A D F^{*}=\inf _{\tau \in T} A D F(\tau) .
\end{aligned}
$$


Değişkenler arasında eşbütünleşme ilişkisinin varlığının tespit edilmesinden sonra kısa ve uzun dönem denklemlerinin elde edilmesi amacıyla FMOLS ve CCR yöntemlerinden yararlanmıştır. FMOLS tahmincisi Phillips ve Hansen (1990), CCR tahmincisi ise Park (1992) tarafından önerilmiştir. Her iki tahminci de eşbütünleşme denklemi ile artıklar arasındaki uzun dönemli korelasyon nedeniyle ortaya çıkan sorunları elimine etmek amacıyla yarı parametrik bir düzeltme kullanmaktadır. FMOLS ve CCR tahmincileri, bağımlı ve bağımsız değişkenlerle ilgili gerekli dönüşümleri yaptıktan sonra en küçük kareler yönteminin uygulanmasıly elde edilmektedir. FMOLS ve CCR tahmincileri, yapısal kırılmalı eşbütünleşme testinden elde edilen kırılma tarihleri modele kukla değişken olarak eklenerek yapısal kırımaların dikkate alınmasına imkan sağlamaktadır. Her iki yöntem sayesinde içsellik sorunu asimtotik olarak ortadan kaldırılmaktadır (Phillips ve Hansen, 1990; Park, 1992).

\section{BULGULAR}

Analizde kullanılan değişkenlerin durağanlıklarını test etmek için ilk olarak ADF ve Phillips-Perron birim kök testleri kullanılmıştır. ADF ve Phillips-Perron birim kök testlerine ilişkin sonuçlar Tablo 3'de yer almaktadır:

Tablo 3 incelendiğinde, ADF birim kök test sonucuna göre gerek sabit terimli sonuçlar açısından BE değişkeni birinci farklarında, CA değişkeninin ise düzey değerinde durağan oldukları görülmektedir. Sabit terim ve trendli sonuçlar açısından ise hem BE hem de CA değişkenleri birinci farkında durağandır. Phillips-Perron birim kök test sonucuna göre gerek sabit terimli sonuçlar açısından her iki değişken birinci farklarında, sabit terim ve trendli sonuçlar açısından ise $B E$ değişkeni düzeyde, CA değişkeni birinci farkında durağandır. Serilerde yapısal kırılmaların olması durumunda ADF ve Phillips-Perron testleri hatalı sonuçlar vermektedir. Bu nedenle çalışmada bir yapısal kırılmaya izin veren Zivot-Andrews birim kök testi uygulanmıştır. Sonuçlar Tablo 4'de yer almaktadır:

Tablo 4: Zivot-Andrews Birim Kök Test Sonucu

\begin{tabular}{llll}
\hline Değişkenler & Model & Kırılma Tarihi & istatistiği \\
\hline BE & A & $2013: Q 1$ & $-3.844(3)$ \\
& B & $2009: Q 2$ & $-3.901(3)$ \\
& C & $2010: Q 2$ & $-3.608(3)$ \\
\hline CA & A & $2010: Q 3$ & $-4.546(2)$ \\
& B & $2013: Q 2$ & $-3.395(2)$ \\
& C & $2010: Q 3$ & $-4.938^{*}(2)$ \\
\hline$\Delta B E$ & A & $2013: Q 1$ & $-6.285^{* * *}(1)$ \\
& B & $2007: Q 2$ & $-6.083^{* * *}(1)$ \\
& C & $2007: Q 1$ & $-6.285^{* * *}(1)$ \\
\hline \multirow{2}{*}{ CA } & A & $2009: Q 2$ & $-6.959^{* * *}(1)$ \\
& B & $2010: Q 4$ & $-6.064^{* * *}(1)$ \\
& C & $2009: Q 2$ & $-6.997^{* * *}(1)$
\end{tabular}

Not: Parantez içindeki değerler Akaike bilgi kriterine göre belirlenengecikme uzunluğunu göstermektedir. ${ }^{* * * *},{ }^{* *},{ }^{*}$ sırasıyla $\% 1, \% 5$ ve $\% 10$ anlamlılık düzeylerini ifade etmektedir. Model $A$, B ve $C$ sırasıyla düzeyde, trendde ve sabit ve trendde kırılmayı göstermektedir. $\Delta$ değişkenlerin birinci dereceden farkını göstermektedir. Model A için \%1, \%5 ve \%10 önem düzeyindeki kritik değerler sırasıyla $-5.34,-4.94$ ve -4.58 'dir. Model B için \%1, $\% 5$ ve $\% 10$ önem düzeyindeki kritik değerler sırasıyla $-4.80,-4.42$ ve -4.11 'dir. Model C için $\% 1, \% 5$ ve $\% 10$ önem düzeyindeki kritik değerler sırasıyla $-5.57,-5.08$ ve -4.82 'dir.

Tablo 3: ADF ve Phillips-Perron Birim Kök Test Sonuçları

\begin{tabular}{lllll}
\hline Değişkenler & ADF & \multicolumn{3}{c}{ Phillips-Perron } \\
\hline & Sabit Terimli & Sabit Terim ve Trendli & Sabit Terimli & Sabit Terim ve Trendli \\
\hline BE & $0.749(9)$ & $-1.788(9)$ & $-2.060(1)$ & $-4.350^{* * *}(3)$ \\
$\mathrm{CA}$ & $-3.078^{* *}(2)$ & $-2.972(2)$ & $-2.331(1)$ & $-2.237(1)$ \\
$\Delta \mathrm{BE}$ & $-3.406^{* *}(8)$ & $-3.636^{* *}(8)$ & $-10.958^{* * *}(0)$ & $-11.038^{* * *}(0)$ \\
$\Delta \mathrm{CA}$ & $-6.127^{* * *}(0)$ & $-6.114^{* * *}(0)$ & $-6.127^{* * *}(3)$ & $-6.107^{* * *}(3)$ \\
\hline Kritik değerler & $\% 1-3.605$ & $\% 1-4.205$ & $\% 1-3.571$ & $\% 1-4.156$ \\
& $\% 5-2.936$ & $\% 5-3.526$ & $\% 5-2.922$ & $\% 5-3.504$ \\
& $\% 10-2.606$ & $\% 10-3.194$ & $\% 10-2.599$ & $\% 10-3.181$ \\
\hline
\end{tabular}

Not: Parantez içindeki değerler Akaike bilgi kriterine göre belirlenen gecikme uzunluğunu göstermektedir. ${ }^{* * * * * *}{ }^{* *}$ sırasıyla \%1, \%5 ve \%10 anlamlılık düzeylerini ifade etmektedir. $\Delta$ değişkenlerin birinci dereceden farkını göstermektedir. 
Tablo 4 incelendiğinde, Model A, B ve C için $B E$ ve $C A$ değişkenlerinin düzey değerleri için tek yapısal kırılma altında serilerin durağan olmadığını söyleyen sıfır hipotezi reddedilememektedir. Değişkenlerin birinci farklarına ilişkin Zivot-Andrews birim kök test sonuçlarını incelediğimizde ise sıfır hipotezinin reddedildiği görülmektedir. Kırılma tarihleri incelendiğinde, 1 Ocak 2013 tarihi itibariyle devlet katkısının uygulanmaya başlaması ile bireysel emeklilik sisteminde meydana gelen değişimi göstermektedir. i̇ç talebin canlanması, dış ticaret açığının artması ve küresel borç krizinin etkisi ile birlikte 2010 yılında cari açık rekor seviyelere ulaşmıştır. Her iki değişkenin de birinci dereceden bütünleşik oldukları söylenebilmektedir. Dolayısıyla, değişkenler arasında uzun dönemli bir ilişki olup olmadığının araştırılması gerekmektedir.

Çalışmada, değişkenler arasındaki uzun dönemli ilişki araştıııırken, tek yapısal kırılmaya izin veren Gregory-Hansen eşbütünleşme testinden yararlanılmaktadır. Tablo 5'de, Gregory-Hansen eşbütünleşme testine ilişkin $A D F^{*}, Z_{t}^{*}$ ve $Z_{a}^{*}$ test istatistik değerleri ve kırılma tarihleri yer almaktadır.

Tablo 5 incelendiğinde, sabitte değişimi dikkate alan model için \%10 önem düzeyine, sabit ve trendde ve rejimde değişimi dikkate alan modeller için ise
$\% 5$ önem düzeyinde $A D F^{*}$ ve $Z_{t}^{*}$ test istatistiklerinin mutlak olarak kritik değerlerden büyük olduğu, dolayısıyla tek yapısal kırılma altında eşbütünleşmenin olmadığını söyleyen sıfır hipotezinin reddedildiği görülmektedir. Bu durum, yapısal kırılma altında değişkenler arasında uzun dönemli ilişkinin varlığını ifade etmektedir. Kırılma tarihleri incelendiğinde, 2012 yılında bireysel emeklilik sisteminde çok önemli düzenlemeler yapılmıştır. Bu yılda yapılan düzenlemelerden en göze çarpan ve sistemi olumlu olarak en fazla etkileyen düzenleme sistemde ödenen katkı paylarının vergi matrahından düşülmesine dayanan teşvik sisteminden, katılımcıların hesaplarına devlet tarafından doğrudan yapılan ve "devlet katkısı" olarak adlandırılan teşvik sistemine geçilmesidir. Bireysel emeklilik sisteminde yaşanan olumlu gelişme tasarrufların arttırılmasına neden olarak cari açığı da pozitif olarak etki etmiştir.

Değişkenler arasında eşbütünleşme ilişkinin varlığının tespit edilmesi nedeniyle, çalışmada değişkenler arasındaki kısa ve uzun dönem ilişkiler araştırımıştır. Bu amaçla modele yapısal kırılmaların dahil edilmesine izin veren FMOLS ve CCR eşbütünleşme denklemlerinden yararlanılmıştır. Tablo 6'de BE ve CA değişkenleri arasındaki uzun dönemli ilişkiyi gösteren FMOLS ve CCR model tahmin sonuçları yer almaktadır.

Tablo 5: Gregory-Hansen Eşbütünleşme Test Sonucu

\begin{tabular}{|c|c|c|c|}
\hline Model & Kırılma Tarihi & ADF $^{*}, Z_{t}^{*}$ ve $Z_{a}^{*}$ Test İstatistikleri & \\
\hline \multirow[t]{3}{*}{ Sabitte Değişim } & 2012:Q4 & $\mathrm{ADF}^{*}$ & $-4.35^{*}(5)$ \\
\hline & 2012:Q2 & $Z_{t}^{*}$ & $-4.10(5)$ \\
\hline & 2012:Q2 & $Z_{a}^{*}$ & $-25.16(5)$ \\
\hline \multirow[t]{3}{*}{ Sabit ve Trendde Değişim } & 2012:Q4 & $\mathrm{ADF}^{*}$ & $-6.10^{* * *}(5)$ \\
\hline & 2012:Q3 & $\mathrm{Z}_{\mathrm{t}}^{*}$ & $-5.78^{* * *}(5)$ \\
\hline & 2012:Q3 & $\mathrm{Z}_{a}^{*}$ & $-40.75(5)$ \\
\hline \multirow[t]{3}{*}{ Rejim Değişimi } & 2013:Q1 & $\mathrm{ADF}^{*}$ & $-5.37^{* *}(4)$ \\
\hline & 2012:Q3 & $Z_{t}^{*}$ & $-5.28^{* *}(4)$ \\
\hline & 2012:Q3 & $\mathbf{Z}_{a}^{*}$ & $-35.36(4)$ \\
\hline
\end{tabular}

Not: Parantez içindeki değerler Akaike bilgi kriterine göre belirlenen gecikme uzunluğunu göstermektedir. $A D F^{*}, Z_{t}^{*}$ ve $Z_{a}^{*}$ sırasıyla $A D F$ birim kök testini, Phillips $Z_{t}$ ve $Z$ testlerinin bilinmeyen bir zamanda rejim değişimine izin verecek şekilde genişletilmiş halini göstermektedir. $\mathrm{ADF}^{*}, Z_{\mathrm{t}}^{*}$ ve $Z_{a}{ }^{*}$ testlerine ilişkin kritik değerler Gregory-Hansen (1996) çalışmasından elde edilmiştir. ${ }^{* * *},{ }^{* *},{ }^{*}$ sırasıyla \% $1, \% 5$ ve $\% 10$ anlamlılık düzeylerini ifade etmektedir. Sabitte değişim modeline ilişkin $A D F^{*}, Z_{t}^{*}$ ve $Z_{a}^{*}$ istatistikleri için \%1, \%5 ve \%10 önem düzeyindeki kritik değerler, sırasıyla $-5.13,-4.61$ ve $-4.34 ;-5.13,-4.61$ ve $-4.34 ;-50.07,-40.48$ ve $-36.19^{\prime}$ dur. Sabit ve trendde değişim modeline ilişkin ADF* $Z_{t}^{*}$ ve $Z_{a}^{*}$ istatistikleri için \%1, \%5 ve \%10 önem düzeyindeki kritik değerler, sırasıyla $-5.45,-4.99 v e-4.72 ;-5.45,-4.99 v e-4.72 ;-57.28,-47.96$ ve -43.22 'dür. Rejim değişim modeline ilişkin ADF* $Z_{t}^{*}$ ve $Z_{a}^{*}$ istatistikleri için \%1, \%5 ve \%10 önem düzeyindeki kritik değerler, sırasıyla -5.47, -4.95 ve $-4.68 ;-5.47,-4.95$ ve $-4.68 ;-57.17,-47.04$ ve $-41.85^{\prime}$ dir. 
Tablo 6: FMOLS ve CCR Uzun Dönem Denklemleri

\begin{tabular}{lll}
\hline Değişkenler & FMOLS & CCR \\
\hline BE & $-1.647107^{*}$ & $-1.650145^{*}$ \\
& $(-1.705624)$ & $(-1.702913)$ \\
Sabit & -0.026403 & -0.026515 \\
& $(-1.617132)$ & $(-1.662405)$ \\
Kukla Değişken & 0.027802 & 0.027938 \\
& $(1.621786)$ & $(1.605426)$ \\
\hline
\end{tabular}

Not: Parantez içindeki değerler t istatistiklerini göstermektedir. ${ }^{* * * *},{ }^{* *},{ }^{*}$ sırasıyla \%1, \%5 ve \%10 anlamlılık düzeylerini ifade etmektedir. Kukla değişkeni için 2012:Q2 dönemine kadar sıfır, bu dönemden sonra bir değeri verilmiştir. Sabit ise modeldeki sabit terimi göstermektedir. Modelde bağımlı değişken olarak CA değişkeni alınmıştır.

Tablo 7: FMOLS ve CCR Kısa Dönem Denklemleri

\begin{tabular}{lll}
\hline Değişkenler & FMOLS & CCR \\
\hline$\Delta$ BE & -0.349680 & -0.405443 \\
& $(-1.171301)$ & $(-0.731989)$ \\
Hata(-1) & $-0.166149^{* * *}$ & $-0.166303^{*}$ \\
& $(-2.624501)$ & $(-2.590511)$ \\
Sabit & -0.000539 & -0.000537 \\
& $(-0.374380)$ & $(0.668808)$ \\
\hline
\end{tabular}

Not: Parantez içindeki değerler $\mathrm{t}$ istatistiklerini göstermektedir. ${ }^{* * *},{ }^{* *},{ }^{*}$ sırasıyla $\% 1, \% 5$ ve $\% 10$ anlamlılık düzeylerini ifade etmektedir. Hata(-1) hata düzeltme katsayısını, sabit modeldeki sabit terimi göstermektedir. Modelde bağımlı değişken olarak CA değişkeni alınmıştır. $\Delta$ değişkenlerin birinci dereceden farkını göstermektedir.

Tablo 6 incelendiğinde, uzun dönemde cari açık ile bireysel emeklilik fonları arasında negatif yönlü bir ilişkinin olduğu görülmektedir. Diğer bir ifadeyle bireysel emeklilik fonları, cari açığın artmasına neden olmaktadır. Tablo 7'da CA ve BE değişkenleri arasındaki kısa dönemli ilişkinin incelendiği model tahmin sonuçları yer almaktadır:

Tablo 7 incelendiğinde, bireysel emeklilik fonu değişkeninin, kısa dönemde cari açık üzerinde anlamlı bir etkiye sahip olmadığı görülmektedir. Hata düzeltme katsayısının 0 ile - 1 arasında olması modelin durağan olduğunu, kısa dönemde cari açıkta meydana gelen şokun uzun dönemde ortadan kalktığını ifade etmektedir. Elde edilen sonuçlara göre, cari açıkta kısa dönemde gelen şokların bir dönem (üç ay) sonra $\% 16$ 'sı düzelmektedir ve söz konusu etki 6 dönemde (yaklaşık 1.5 yıl sonra) ortadan kalkmaktadır.

Cari açık ve bireysel emeklilik fonları arasındaki kısa ve uzun dönem ilişkiler tespit edildikten sonra, söz konusu iki değişken arasındaki kısa dönemli nedensellik ilişkisi araştırılmıştır. Bu amaçla Toda-Yamamoto nedensellik testinden yararlanılmıştır. Toda-Yamamoto nedensellik testi için ilk olarak uygun VAR modeli tahmin edilmiştir. Oluşturulan VAR modeline ilişkin optimal gecikme uzunluğu Tablo 8'de gösterilmektedir. Tablo 8'deki sonuçlar incelendiğinde, AIC ve FPE bilgi kriterlerine göre optimal gecikme uzunluğu 3 olarak belirlenmiştir.

Tablo 8: Optimal Gecikme Uzunluğunun Belirlenmesi

\begin{tabular}{lcccccc}
\hline Lag & LogL & LR & FPE & AIC & SC & HQ \\
\hline 0 & 308.9306 & & $5.99 \mathrm{e} 09-$ & -13.25785 & -13.09884 & -13.19828 \\
\hline 1 & 341.2228 & $58.96844^{*}$ & $1.75 \mathrm{e} 09-$ & -14.48795 & $14.1699-^{*}$ & $14.36882-^{*}$ \\
\hline 2 & 344.7810 & 6.188077 & $1.79 \mathrm{e} 09-$ & -14.46874 & -13.99170 & -14.29004 \\
\hline 3 & 350.0008 & 8.624006 & $1.70 \mathrm{e} 09-*$ & $14.52177-*$ & -13.88572 & -14.28350 \\
\hline 4 & 350.9040 & 1.413786 & $1.96 \mathrm{e} 09-$ & -14.38713 & -13.59207 & -14.08930 \\
\hline
\end{tabular}

* kriter tarafından seçilen gecikme uzunluğunu ifade etmektedir.

LR: sequential modified LR test istatistği

FPE: Final prediction error

AIC: Akaike bilgi kriteri

SC: Schwarz bilgi kriteri

HQ: Hannan-Quinn bilgi kriteri 
Tablo 9: Bireysel Emeklilik Fonları ve Cari Açık Arasındaki Granger Nedensellik Test Sonuçları

\begin{tabular}{lllll}
\hline Nedenselliğin Yönü & $x^{2}$ Test İstatistiği & Sıfır Hipotezi & Karar \\
\hline BE & CA & 0.711696 & Bireysel emeklilik fonları, cari açığın nedeni değildir & Kabul \\
CA & BE & 3.590765 & Cari açık bireysel emeklilik fonlarının nedeni değildir & Kabul \\
\hline
\end{tabular}

Not: *** ve *** sırasıyla $0.10,0.05$ ve 0,01 düzeyinde istatistiksel olarak anlamlılığı ifade etmektedir. $0.10,0.05$ ve 0.01 düzeyleri için kritik değerler sırasıyla 4.60517, 5.99147 ve 9.21034 'dür.

Tablo 10: Bireysel Emeklilik Fonları ve Cari Açık Arasındaki Toda-Yamamoto Nedensellik Test Sonuçları

\begin{tabular}{lclll}
\hline \multirow{2}{*}{ Nedenselliğin Yönü } & $\begin{array}{l}\chi^{2} \text { Test } \\
\text { İstatistiği }\end{array}$ & Sıfır Hipotezi & Karar \\
\hline BE & CA & 1.196443 & Bireysel emeklilik fonları, cari açığın nedeni değildir & Kabul \\
CA & BE & 2.988279 & Cari açık bireysel emeklilik fonlarının nedeni değildir & Kabul \\
\hline
\end{tabular}

Not: **** ve *** sırasıyla $0.10,0.05$ ve 0,01 düzeyinde istatistiksel olarak anlamlılığı ifade etmektedir. . 0.10, 0.05 ve 0.01 düzeyleri için kritik değerler sırasıyla 4.60517, 5.99147 ve 9.21034 'dür.

Optimal gecikme uzunluğunun belirlenmesinin ardından, oluşturulan 3 gecikmeli VAR modelinin artıklarına ilişkin LM otokorelasyon ve White farklı varyans testleri uygulanmıştır. 1 gecikmeli LM otokorelasyon test istatistiği 0.3368 ve White değişen varyans test istatistiği 29.9936 olarak bulunmuştur. Gerek LM otokorelasyon testi gerekse White değişen varyans testi için sıfır hipotezinin reddedilemediği ve dolayısıyla kurulan VAR modelinde otokorelasyon ve farklı varyans sorunları ile karşılaşılmadığı sonuçlarına ulaşılmıştır. Oluşturulan 3 gecikmeli VAR modelinin gerekli varsayımları sağladığı görülmektedir. Ayrıca, değişkenler arasındaki Granger nedensellik testi Tablo 9'daki gösterilmektedir:

Tablo 9'da yer alan Granger nedensellik test sonuçları incelendiğinde, bireysel emeklilik fonlarından cari açığa ve cari açıktan bireysel emeklilik fonlarına doğru Granger nedensellik ilişkisinin olmadığı görülmektedir. Toda-Yamamoto nedensellik test sonucu ise, Tablo 10'da gösterilmiştir.

Tablo 10'a göre, bireysel emeklilik fonlarının cari açığın nedeni olmadığını söyleyen sıfır hipotezi reddedilememektedir. Benzer şekilde, cari açığın bireysel emeklilik fonlarının nedeni olmadığını söyleyen sıfır hipotezinin de reddedilemediği görülmektedir. Bu durum değişkenler arasında nedensellik ilişkisinin olmadığını ifade etmektedir.

\section{SONUÇ}

Türkiye'de 2003 yılından itibaren uygulamaya başlanılan bireysel emeklilik sistemi, sadece bir sosyal güvenlik faaliyeti olarak görülmemekte, aynı zamanda ülkedeki tasarruf açığını ve buna bağlı ekonomik sorunlarında gidereceği kalkınma planlarında sıkla öngörülmektedir. Bu kapsamda Türkiye için yapılan çalışmalarda, genellikle tasarruf açığının bireysel emeklilik sistemiyle aşılacağı yönünde politika önerilerinde bulunulmuştur (Sezgin vd (2015), Çoban ve Çoban (2016))

Bu çalışmada ise, 2004:Ç1-2016:Ç2 dönemi dikkate alınmış olup, bireysel emeklilik fonları ve cari açık arasındaki kısa ve uzun dönemli ilişki incelenmiştir. Yapılan analiz sonucunda, uzun dönemde bireysel emeklilik fonlarında meydana gelen artışların, cari açığı olumsuz etkilediği görülmüştür. Kısa dönemde ise, bireysel emeklilik fonları, cari açığı etkilememektedir. Ayrıca, kısa dönemde ortaya çıkan şokların üç ay sonra \%16'sının ortadan kalktığı ve sistemin yaklaşık iki yılda yeniden dengeye geldiği bulunmuştur.

Elde edilen sonuçlar ışığında, kısa dönemde bireysel emeklilik fonları ve cari açık arasında bir ilişkinin olmaması, biriken fonların cari açık üzerinde etki yaratacak bir düzeyde olmadığını göstermektedir. Ayrıca uzun dönemde bu ilişkinin negatif bir şekilde var olması ise, fon sahiplerinin uzun dönemli yatırımlardan kaçındığı veya verilen teşviklerin kamusal tasarrufları azalttığı böylece kamusal borçlanmayı arttırarak cari açık üzerinde negatif bir etki yarattığı söylenebilmektedir. Bu sonuçlar, Bebczuk ve Musalem (2006), Yaraşır ve Yılmaz (2011), Tülümce (2013), Sezgin vd (2015), Çoban ve Çoban (2016), Başar vd (2016)'nin elde ettiği sonuçların aksine bireysel emeklilik fonlarının uzun dönemde cari açık üzerinde negatif bir etki yarattığını göstermektedir.

Sonuç olarak, 2003 yılından beri uygulanılan bireysel emeklilik sistemi, ülke içinde var olan tasarruf açığını gidermemekte olup, cari açık üzerinde negatif bir etki yaratmaktadır. Bu durumda uygulanacak 
politikalara bakıldığında, özellikle bireysel emeklilik sisteminin tabana yayılması gerektiği bunun içinde gelir düzeyinin iyileştirilmesi ve gelir adaletsizliğinin giderilerek bireylerin tasarruf yapabilme potansiyeli- nin arttırılması gerekmektedir. Öte yandan ülke içinde ekonomik istikrarın yeniden sağlanarak yurtiçi ve yurtdışı fon sahiplerine güven ortamı yaratılmalıdır.

\section{KAYNAKLAR}

4632 Sayılı Bireysel Emeklilik Tasarruf ve Yatırım Sistemi Kanunu http://www.mevzuat.gov.tr/ MevzuatMetin/1.5.4632.pdf, (15.01.2017).

Abbasoğlu, O. F., İmrohoroğlu, A. ve Kabukçuoğlu, A. (2017) "Is the Turkish Current Account Deficit Sustainable?" Koç University-TÜSIAD Economic Research Forum Working Paper Series, No. 1705.

Alessie, R., Angelini, V. ve van Santen, P. (2013) “Pension Wealth and Household Saving in Europe: Evidence from SHARELIFE" European EconomicReview, 63: 308-328.

Ando, A. ve Modigliani, F. (1963) "The "Life Cycle" Hypothesis of Saving: Aggregate Implications and Tests" The American Economic Review, 53(1): 55-84.

Anton, J-I, De Bustillo, R. M. ve Fernandez-Macias, E. (2014) "Supplementary Private Pensions and Saving: Evidence from Spain" Journal of Pension Economics \& Finance, 13(4): 367-388.

Attanasio, O.P.ve De Leire, T. (2002) "The Effect of Individual Retirement Accounts on Household Consumption and National Saving" The Economic Journal, 112(481): 504-538.

Başar, S., Eren, M. ve Bozma, G. (2016) "Bireysel Emeklilik, Tasarruf Oranı ve Cari Açık Arasındaki Ilişkiler: OECD Ülkeleri Üzerine Bir Uygulama" International Conference on Eurasian Economies Bildiri Kitabı: 591597, (15.01.2017).

Başarır, Ç. ve Erçakar, M. E. (2016) "An Analysis of the Relation between Crude Oil Prices, Current Account Deficit and Exchange Rates: Turkish Experiment" International Journal of Economics and Finance, 8(11): 48- 59.

Bebczuck, R.N. ve Musalem, A. R. (2006) "Pensions and Saving: New International Panel Data Evidence" Documento de Trabajo Nro. 61.

Beşel, F. (2017) "Oil Prices Affect Current Account Deficit: Empirical Evidence From Turkey" Journal of Applied Research in Finance and Economics, 3(2): 13-21.

Brückner, M. ve Pappa, E. E. (2013) “On the Relationship Between Domestic Savings and the Current Account in Poor Countries: Evidence and Theory" http://apps.eui. eu/Personal/Pappa/Papers/RelatDomSav_Sept2013. pdf (15.01.2017).
Cagan, P. (1965) "The Effect of Pension Plans on Aggregate Saving: Evidence from a Sample Survey" National Bureau of Economic Research, Occasional Paper no. 95. New York: Columbia Univ. Press.

Catalan, M. ve Magud, N. E. (2012) “A Tradeoff between the Output and Current Account Effects of Pension Reform", IMF Working Paper, WP/12/283.

Çiğdem, G. (2017) "Investigation of the Relationship between Current Account Deficit and Savings in MENA Economies: An Empirical Approach" International Journal of Economics and Research, 8(3): 1-6.

Çoban, A. ve Çoban, O. (2016) "Historical Development of Individual Pension System: A Theoretical Analysis" Journal of Emerging Issues in Economics, Finance and Banking, 5(2): 1992-2008.

Çolak, Ö.F. ve Öztürkler, H. (2012) "Tasarrufun Belirleyicileri: Küresel Tasarruf Eğiliminde Değişim ve Türkiye'de Hanehalkı Tasarruf Eğiliminin Analizi" Bankacılar Dergisi, Eylül 2012, No: 82.

Dinçer, N.N. ve Yaşar, P. (2015) "Identification of Current Account Deficit: The Case of Turkey" The International Trade Journal, 29(1): 63-87.

Doğruel, F. ve Doğruel, A. S. (2010) “Türkiye'de Cari Açık: Temel Sorunlar ve Dinamikler"Turan Subaşat ve Hakan Yetkiner (edit.) Küresel Kriz Çerçevesinde Türkiye'nin Cari Açık Sorunsalı, 1. Basım, Ankara, Efil Yayınevi, ISBN: 978605-4334-04-9.

DÜNYA BANKASI (2013) "Yüksek Büyümenin Sürdürülebilirliği:Yurtiçi Tasarrufların Rolü Türkiye Ülke Ekonomik Raporu" Rapor No. 66301-TR.

Eğilmez, M. (2013) "iç̧ Tasarruflarla Cari Açık İlişkisi", http://www.mahfiegilmez.com/2013/03/ictasarruflarla-cari-ack-iliskisi.html (15.01.2017).

Eren, O. ve Illeri, Ş. G. (2015) "Government Subsidized Individual Retirement System" TCMB Working Paper, No. 15/20.

Feldstein, M. (1978) "Do Private Pensions Increase National Savings?" Journal of Public Economics, 10: 277-293.

Göçer, I ve Peker, O. (2014) "Yabancı Doğrudan Yatırımların Cari İşlemler Dengesi Üzerindeki Etkileri: 
Türkiye, Çin ve Hindistan Örnekleminde Çoklu Yapısal Kırılmalı Eşbütünleşme Analizi" BDDK Bankacılık ve Finansal Piyasalar, 8(1): 87-116.

Gregory, A.W. ve Hansen, B. E. (1996) “Residual-Based Tests for Cointegration in Models with Regime Shifts" Journal of Econometrics, 70: 99-126.

Gustman, A.L. ve Steinmeier, T. L. (1998) "Effect of Pension on Savings: Analysis with Data from the Health and Retirement Study" NBER Working Paper, No. 6681.

Insel, A., Kayıkçı, F. (2012) “Evaluation of Sustainability of Current Account Deficits in Turkey" Modern Economy, 3: 43-50.

İsseveroğlu, G. ve Hatunoğlu Z. (2012) “Türkiye'de Bireysel Emeklilik Sisteminin Makro Ekonomik Dinamiklere Etkisi Kapsamında Swot Analizi" Muhasebe ve Finansman Dergisi, 56: 155-174.

KALKINMA BAKANLIĞI (2017), http://www.kalkinma. gov.tr/Pages/EkonomikSosyalGostergeler.aspx (16.01.2017).

Kara, H. ve Sarıkaya, Ç. (2014) "Current Account Deficit in Turkey: Cyclical or Structural?" Koç University-TÜSIAD Economic Research, Forum Working Paper Series, No. 1420.

Katona, G. (1965) "Private Pensions and Individual Saving" Monograph No. 40, Survey Research Center Institute for Social Research The University of Michigan.

Kaygısız, A. D., Kaya, D. G. ve Kösekahyaoğlu, L. (2016) "Türkiye'de Tasarruf, Yatırım, Cari Açık ve Büyüme: 19802014 Dönemi Üzerine Bir Nedensellik İlişkisi Analizi" Çankırı Karatekin Üniversitesi Sosyal Bilimler Enstitüsü Dergisi, 7(1): 273-300.

Knight, M. ve Scacciavillani, F. (1998) "Current Accounts: What Is Their Relevance for Economic Policymaking?" IMF Working Paper, WP/98/71.

Krugman, P. R. ve Obstfeld, M. (1997) International Economics: Theory and Policy, Addison Wesley, 4nd Edition, USA.

Lachowska, M. ve Myck, M. (2015) “The Effect of Public Pension Wealth on Saving and Expenditure" IZA DP No. 8895.

Leszczuk, J. ve Pojar, S. (2016) "Denmark's Current Account Surplus?" European Commission, Economic Brief 18.

Modigliani, F., Brumberg, R. (1954) "Utility Analysis and the Consumption Function: An Interpretation of Cross Section Data" Kurihara K (eds.) In Post Keynesian Economics, New Brunswick, N.J.: Rutgers Univ. Press.
Munnell, A. H. (1976) "Private Pensions and Savings: New Evidence" Journal of Political Economy, 84(5): 10131032.

Munnell, A. H. ve Yohn, F. O. (1991) “What Is the Impact of Pension on Saving ?", Federal Reserve Bank of Boston, Working Paper, No. 91-5.

Murat, S., Hobikoğlu, E. H. ve Dalyancı, L. (2014) "Structure and Sustainability of Current Account Deficit in Turkish Economy" Procedia - Social and Behavioral Sciences, 150: 977 - 984.

Murphy, P. L. ve Musalem, A. R. (2004) “Pension Funds and National Saving"World Bank, WPS3410.

OECD (2016) Pension Markets in Focus.

Olivei, G. P. (2000) “The Role of Savings and Investment in Balancing the Current Account: Some Empirical Evidence from the United States" New England Economic Review.

Özdamar, G. (2015) “Factors Affecting Curent Account Balance of Turkey: A Survey with the Cointegrating Regression Analysis" Journal of Business, Economics \& Finance, 4(4): 633-658.

Özel, Ö. Ve Yalçın, C. (2013a) “Gelişmekte Olan Ülkelerde Özel Emeklilik Reformlarının Yurtiçi Tasarruf Oranlarına Etkisi: Ampirik Bulgular" TCMB Ekonomi Notları, Sayı.2013-06.

Özel, Ö. ve Yalçın, C. (2013b) "Yurtiçi Tasarruflar ve Bireysel Emeklilik Sistemi: Türkiye'deki Uygulamaya illişkin Bir Değerlendirme" TCMB Çalışma Tebliği No: 13/04.

Park, J. Y. (1992) "Canonical Cointegrating Regressions" Econometrica, 60(1): 119-143.

Phillips, P. C. B.ve Hansen, B. E. (1990) "Statistical Inference in Instrumental Variables Regression with I(1) Process" Review of Economics Studies, 57(1): 99-125.

Rijckeghem, C. V. ve Üçer, M (2008) “Türkiye'de Özel Tasarruf Oranının Gelişimi ve Belirleyicileri: Ekonomi Politikaları Açısından Bir Değerlendirme", EAF Araştırma Notu 08-02.

Schimmelpfennig, A. (2000) "Pension Reform, Private Saving, and the Current Account in Small Open Economy" IMF Working Paper WP/00/171.

Selim, S. ve Çelik, O. (2014)“Bireysel Emeklilik Fonlarını Belirleyen Faktörler: OECD Örneği" Selçuk Üniversitesi iktisadi ve İdari Bilimler Fakültesi Sosyal ve Ekonomik Araştırmalar Dergisi,14(28): 188-208.

Sezgin, Z., Sevim, C. ve Kalyoncu, F. (2015) "Türkiye Ekonomisinde Cari Açık Sorunu: Tasarrufların Önemi ve Bireysel Emeklilik Sistemi" Kırıkkale Üniversitesi Sosyal Bilimler Dergisi, 5(2): 227-240. 
Soydan, A. (2016) “Does Credit Growth 'Cause' Current Account Deficits? Evidence from Turkey" Advances in Economics and Business, 4(2):102-116.

TCMB (2015) "Tasarruf-Yatırım Dinamikleri ve Cari İşlemler Dengesi Gelişmeleri".

Turan, Z., Barak, D., Berkman, A. N. ve Nakipoğlu A. (2016) "Sustainability of Current Account Deficit in Turkey (1989-2014)" International Journal of Economics and Financial Issues, 6(2): 807-812.

Tülümce, S.Y. (2013) “Türkiye'de Üçüz Açığın Ampirik Analizi (1984-2010)" Maliye Dergisi, Temmuz-Aralık, 165: 97-114.

Uyar, H. I. (2012) "Bireysel Emeklilik Sistemi ile Ekonomik Göstergeler Arasındaki İlişkinin İncelenmesi" Mali Çözüm Dergisi, Mart-Nisan, 110: 71-93.

Uygur, E. (2012) "Türkiye'de Cari Açık Tartışması" TEK Tartışma Metni, 2012/25.

Yaraşır, S. ve Yılmaz, B. E. (2011) “OECD Ülkelerinde Özel Tasarruflar: Bir Bakış (1999-2007)"Maliye Dergisi, OcakHaziran, 160: 139-153.
Yılmaz, B.E. ve Yaraşır S. (2009) "Türkiye'de ve OECD Ülkelerinde Tasarruf-Yatırım Açıkları ve Dış Kaynak Intiyacı" Marmara Üniversitesi IIIBF Dergisi, XXVII(II): 97 128.

Yiğitbaş, Ş. B. (2017) "The Relationship between Financial Depth and Current Account Deficit in Turkey" Uluslararası Yönetim iktisat ve Işletme Dergisi, 13(3): 507520.

Yurdakul, F. ve Uçar, B. (2015) “The Relationship Between Current Deficit and Economic Growth: An Empirical Study on Turkey" Procedia Economics and Finance, 26: $101-108$.

Yurdakul, F. ve Cevher, E. (2015) "Determinants of Current Account Deficit in Turkey: The Conditional and Partial Granger Causality Approach" Procedia Economics and Finance, 26: 92 - 100.

Zivot, E. ve Andrews, D.W.K. (1992) "Further Evidence on the Great Crash, the Oil-Price Shock, and the Unit-Root Hypothesis" Journal of Business Economic Statistics, 10(3): 251-270. 